\title{
Arctic Fox (Alopex lagopus) Dens in the Disko Bay Area, West Greenland
}

\author{
SUSSIE M. NIELSEN,${ }^{1}$ VIVI PEDERSEN ${ }^{2}$ and BENTE BANG KLITGAARD ${ }^{3}$
}

(Received 16 August 1993; accepted in revised form 10 May 1994)

\begin{abstract}
Seventeen arctic fox (Alopex lagopus) dens in the Disko Bay area, West Greenland are described regarding location, type, size and vegetation cover. The dens were found in ridges, screes and level ground, mainly in areas of dwarf-scrub heath. The mean number of entrances was $17.8 \pm 18.4 \mathrm{SD}$ (range 1-63), with more than half of the dens having fewer than 10 entrances. For dens in slopes, there was a prevalence for south-facing slopes, but for dens with an open exposure, entrances were most frequently oriented towards the north and east. The dens were not found to be lush green, as reported from several other areas. A visual difference between the den vegetation and the surrounding vegetation could only be recognized at a few den sites. A vegetation analysis revealed a significant difference between the den and the surrounding area in the occurrence of eight plant species. Among the species occurring more frequently on the den than in the adjacent area, Stellaria longipes was the most conspicuous because of its white flowers. This species is therefore suggested as a guide species in the search for new dens in the Disko Bay area. Dens with recent fox activity were larger and more conspicuous than dens without sign of recent activity.
\end{abstract}

Key words: Arctic fox, Alopex lagopus, den site, den vegetation, Disko Bay, West Greenland

RÉSUMÉ. On donne une description des terriers de 17 renards arctiques (Alopex lagopus) dans la région de la baie de Disko, à l'ouest du Groenland, selon l'emplacement, le type, la dimension et le couvert végétal. Ces terriers avaientété creusés dans des crêtes, des éboulis et en terrain plat, surtout dans des zones où la végétation se composait d'arbustes nains. Le nombre d'entrées était de 17,8, avec un écarttype de 18,4 (gamme de 1 à 63), plus de la moitié des terriers ayant moins de 10 entrées. Les terriers creusés dans les talus étaient plutôt exposés au sud, mais ceux qui étaient ouverts avaient leurs entrées orientées le plus fréquemment vers le nord et vers l'est. On n'a pas trouvé de végétation très dense autour du terrier, comme cela avaitété rapporté pour plusieurs autres endroits. On n'a pu faire de différence visuelle entre la végétation du terrier et la végétation à l'entour que sur quelques sites. Une analyse de la végétation a révélé une différence significative entre le terrier même et la zone à l'entour dans la présence de huit espèces de plantes. Parmi les espèces apparaissant plus fréquemment sur le site du terrier que dans la zone à l'entour, Stellaria longipes était la plus visible en raison de ses fleurs blanches. C'est pourquoi on suggère d'utiliser cette espèce comme un guide dans la recherche de nouveaux terriers creusés dans la région de la baie de Disko. Les terriers qui portaient des traces de la présence récente des renards étaient plus grands et plus visibles que les terriers qui ne montraient pas de traces de présence récente.

Mots clés: renard arctique, Alopex lagopus, site du terrier, végétation de terrier, baie de Disko, Groenland occidental

Traduit pour la revue Arctic par Nésida Loyer.

\section{INTRODUCTION}

Arctic foxes (Alopex lagopus) use dens to rear cubs during the breeding season and as shelter for much of the year. Most field studies of foxes are initiated by locating their dens. On foot, this is very time-consuming. Den vegetation often differs from that of the surrounding area (Danilov, 1961; Chesemore, 1969; Eberhardt, 1977; Garrottet al., 1983; Prestrud, 1992). In tundra areas where fox dens can be recognized by their lush green appearance, mapping of dens has been done from the air (Chesemore, 1969; Macpherson, 1969; Ericson and Grundsten, 1980; Garrott et al., 1983; Smits et al., 1988). Knowledge about dens and den sites in areas of similar terrain may increase the success of locating new dens.
Descriptions of arctic fox dens exist from the tundra plains of Alaska (Chesemore, 1969; Eberhardt, 1977; Garrott et al., 1983), from Canada (Macpherson, 1969; Smits et al., 1988), from Siberia (Danilov, 1961; Bannikov, 1969), from the Scandinavian highlands (Zetterberg, 1945; Østbye et al., 1978; Pullainen and Ala-Kotila, 1982), and from Svalbard (Prestrud, 1992). No descriptions of arctic fox dens in the undulate coastal area of Greenland have been made so far. The objectives of this study are 1) to describe dens and den sites of arctic foxes in a coastal area of central West Greenland and to reveal possible factors affecting the construction of the den; 2) to test a fairly rapid and improved method of quantitative vegetation analysis; and 3) to evaluate the prospects of an aerial survey of arctic fox dens in central West Greenland.

\footnotetext{
${ }^{1}$ Zoological Museum, University of Copenhagen, Universitetsparken 15, 2100 Copenhagen $\emptyset$, Denmark

${ }^{2}$ Institute of Population Biology, University of Copenhagen, Universitetsparken 15, 2100 Copenhagen $\emptyset$, Denmark

${ }^{3}$ The Herbarium, The Royal Botanic Gardens, Kew Richmond, Surrey TW9 3AB, United Kingdom

(C) The Arctic Institute of North America
} 


\section{STUDY AREA}

The study was carried out on Disko Island, West Greenland, and on the archipelagos of Kronprinsens Ejlande and Grønne Ejlande, Disko Bay $\left(68-70^{\circ} \mathrm{N}, 51-55^{\circ} \mathrm{W}\right)$ (Fig. 1).

The area is of volcanic origin, mainly tertiary basalt and cretaceous sediments (Escher and Stuart, 1976). The undulate landscape features richly vegetated valleys, extensive flat areas with marsh or heath vegetation, and areas of sandy beach as well as steep, rocky coasts. More detailed information on the study area is given for geology in Escher and Stuart (1976), for vascular plants in Porsild (1920) and Böcher (1959, 1963), for lichens in Lynge (1937) and for mosses in Mogensen (1985, 1986, 1987).

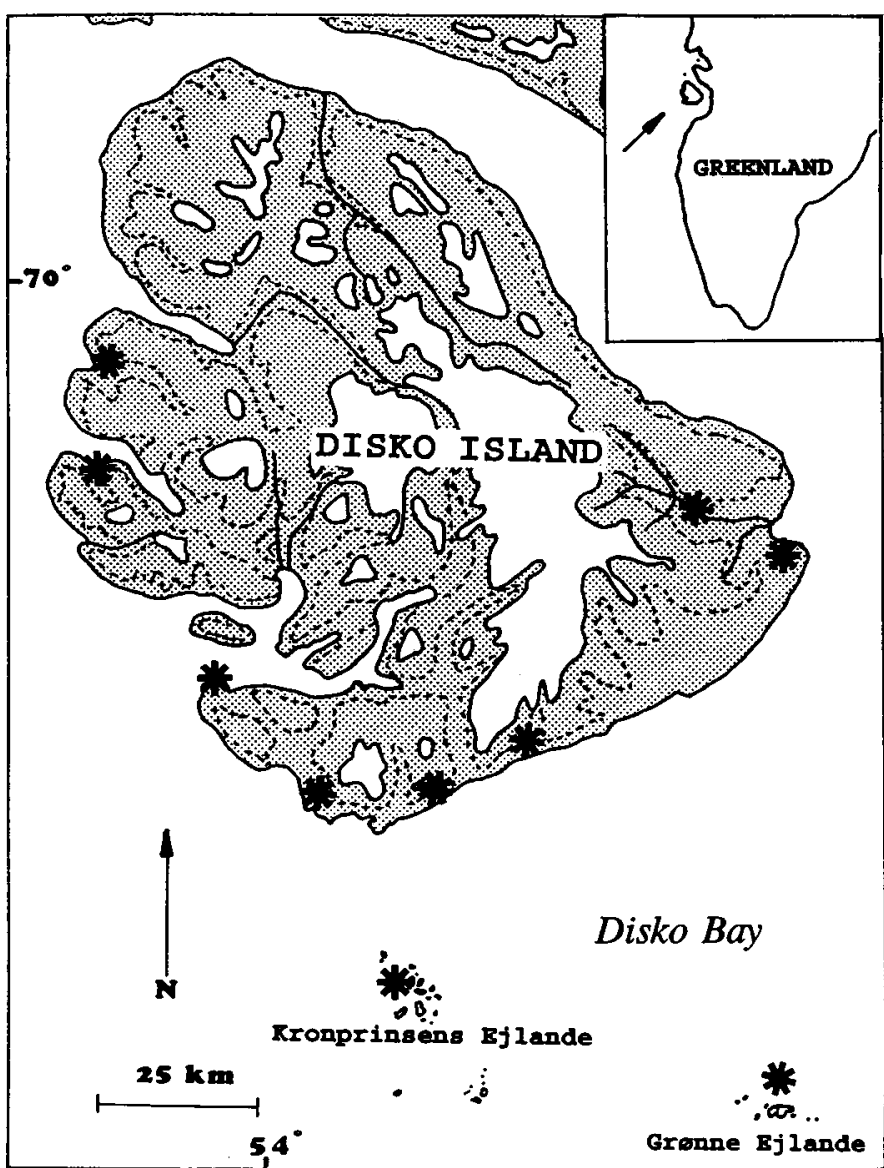

FIG. 1. Map of the study area $(*=$ sites with one or more dens). Dotted line is $300 \mathrm{~m}$ a.s.l. and shaded area denotes the area without glaciers.

The climate is low arctic. The permafrost layer (in level ground) begins to drop by the end of May. From June to September it drops to about $3 \mathrm{~m}$ below the surface. The prevailing winds are from the east and the northeast, except from May to August when southwesterly and westerly winds predominate. Mean monthly temperatures from October 1991 through April 1992 ranged between $-2.4^{\circ} \mathrm{C}$ (October) and $-25.0^{\circ} \mathrm{C}$ (February), and from May through September 1992, between $-5.2^{\circ} \mathrm{C}$ (May) and $5.5^{\circ} \mathrm{C}$ (July), as measured by the weather station at the Arctic Station, Godhavn.

Both the white and the blue colour morph of the arctic fox are common in the area. Marine food sources, such as seabirds, fish and marine invertebrates, are of major importance to the foxes in this area (Nielsen, 1991; Nielsen, in prep.). Small rodents are absent in West Greenland (Salomonsen, 1990).

\section{MATERIALS AND METHODS}

Between May 1990 and September 1992, the location of 17 dens was recorded by random encounters or information from local inhabitants. In June and July each year, known dens were checked for breeding activity, and in August and September 1992, all dens were visited and described as follows.

The vegetation of the den site locality was classified as "heath," "marsh," "barren," or "shore," following Feilberg et al. (1984). The elevation of the den above sea level was recorded. The shortest distance from the den to the coast and to bird colonies (within $15 \mathrm{~km}$ ) was measured from maps (1:10 000). For dens in slopes, the orientation towards the quarters of the globe was recorded. Dens in level ground or on the top of a ridge were noted as having an "open exposure." A den was classified as "rock" if it was in scree or beneath boulders; as "level" if dug in level ground; as "hill" if it was in a ridge (relief more than 1 m) and as "ruin" if it was in the walls of a native house ruin.

The number of den entrances was counted and the distance between the two entrances situated farthest apart (the diameter of the den) measured. Entrances were characterized as "collapsed," "aged" (open but not in use, with many twigs and leaves and no signs of recent activity), or "used" (entrance with no or few leaves and twigs, fresh trails leading into the den or freshly excavated soil). A score for the conspicuousness ("c-score") of the den was given, indicating the contrast between the den vegetation and the surrounding area; " 0 " = no difference at close hand, "1"= difference at close hand, "2" = the den could be recognised from a greater distance $(>100 \mathrm{~m})$.

At ten of the dens known to have been in use during the study period, the vegetation was analyzed, the orientation of each entrance was noted and one soil sample was collected. The sample was taken from a soil pile at an entrance and later analyzed at the Institute of Geology, University of Aarhus, Denmark. Sand grain size was classified using the U.S. Department of Agriculture Classification system (Soil Survey Staff, 1975).

A vegetation analysis combining "line transecting" and "Raunkier's circling" (Mueller-Dombois and Ellenberg, 1974) was used (Fig. 2). The point halfway between the two most distant den entrances was defined as the centre of the den. Two areas were then prepared: 1) the "den area" bordered by the smallest circle containing all the entrances (diameter $=\mathrm{D}$ ), and 2) the "surrounding area" bordered by circles with the diameters D and $2 \times D$. Transect lines with the length of $D$ were drawn from the centre outwards in the four cardinal directions. Eight Raunkier's circles (each $0.1 \mathrm{~m}^{2}$ ) were placed along each transect line at equal intervals, giving a total of 16 Raunkier's circles in each of the two areas. All plant species within a Raunkier's circle were identified. The heights of the tallest individual of both grass and willow (Salix glauca) occurring in the Raunkier's circles were measured. 


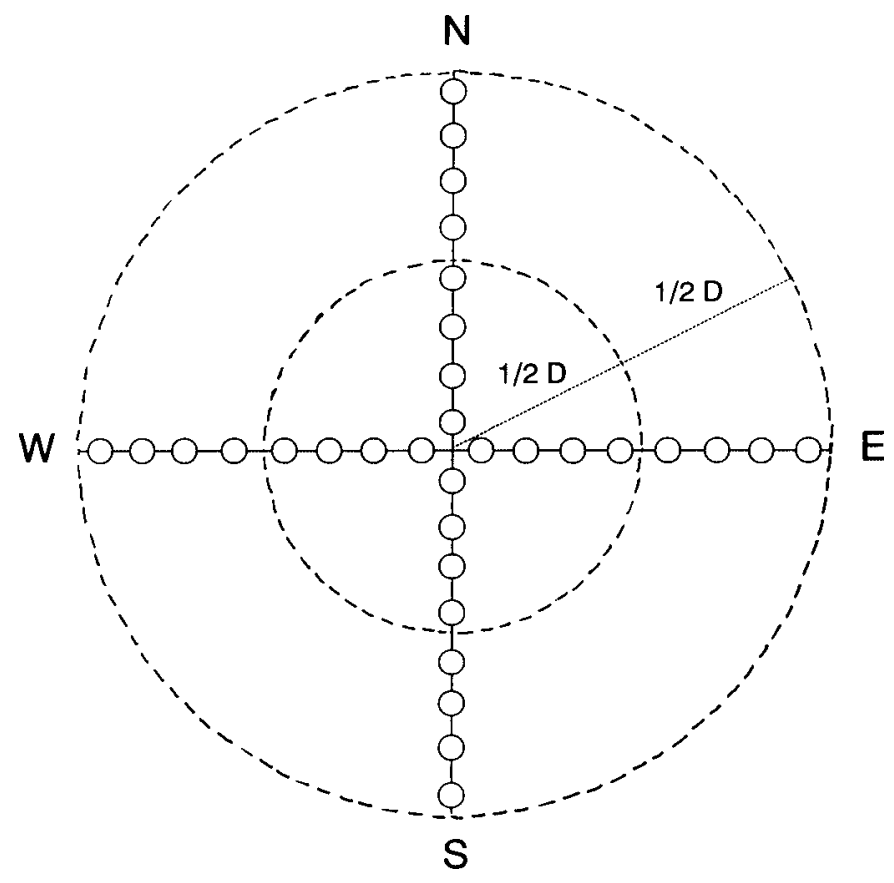

FIG. 2. Schematic outline of the vegetation analysis method; large circles represent the den area and the surrounding area, and small circles the Raunkier's circles.

\section{Data Analysis}

Statistical analyses were performed using Execustat 3.0/PC (Loll, 1993). The relation between the number of entrances and the diameter of the den was examined by simple regression analysis. The mean size (in terms of diameter and number of entrances) of dens of different types, c-scores and use was compared by the Kruskal-Wallis test with Exploratory Data Analysis (McGill et al., 1978) and the signed-ranks test. For dens with an open exposure, the combined number of entrances oriented towards the northwest, north, northeast and east was compared with the number oriented towards the southeast, south, southwest and west using the paired rank test. The difference in conspicuousness and use between den types, and the difference in the occurrence of plant species between the den area and the surrounding area, were examined by the chi-square test (with Yates' correction in cases of one degree of freedom) and by Fisher's exact test. Only plant species found in the Raunkier's circles of at least five dens were analyzed. The difference in mean height of the grass and willow in the den area and in the surrounding area was compared by the paired t-test. The data on heights were transformed logarithmically to obtain normal distribution. The ruin den was excluded from the statistical treatments regarding diameter and vegetation.

\section{RESULTS}

\section{The Den Site}

Fourteen dens were found in areas with dwarf shrub heath, and one in each of the remaining vegetation types - barren, shore and marsh. All dens were below $75 \mathrm{~m}$ above sea level (a.s.l.) and 14 were below $25 \mathrm{~m}$ a.s.l. Eleven dens had an open exposure and six dens were in south-facing slopes. All dens, except for one situated $12.4 \mathrm{~km}$ from the coast, were found less than $1200 \mathrm{~m}$ from the coast, and eleven dens were located within $500 \mathrm{~m}$ of the coast. Four dens were situated within $3 \mathrm{~km}$ of a bird colony: one near nesting great cormorants (Phalacrocorax carbo) (about 30 nesting pairs); one near a colony of both iceland gulls (Larus glaucoides) and glaucous gulls (Larus hyperboreus) (about 30 nesting pairs); and two near the same colony of Arctic terns (Sterna paradisaea) (about 100 birds in 1991; O. Frimer, pers. comm. 1991).

\section{The Den}

Six hill dens, six rock dens, four level dens and one ruin den were found. The mean number of den entrances was 17.8 \pm 18.4 SD (range 1-63). More than half of the dens had less than 10 entrances (Fig. 3). The number of aged and collapsed entrances of the dens ranged from $\mathrm{O}$ to 36 and 0 to 51 respectively.

The mean diameter of the dens was $15.8 \mathrm{~m} \pm 15.3 \mathrm{SD}$ (range 1-38 m, $n=13$ ). A linear relationship was found between the number of entrances and the diameter for all the dens combined and for rock and hill dens, but not for dens in level ground (Fig. 3).

The median den size of different den types did not differ significantly in terms of the number of entrances, but the diameter of level dens was found to be significantly larger than that of other den types (Table 1).

Nine dens were given a c-score of 0 , six dens a c-score of 1 and two dens a c-score of 2 . The median number of total and used entrances was significantly higher for dens given a c-score of 1 and 2 combined, than for dens given a c-score of 0 (Table 1).

Fox activity was recorded and cubs observed at all den types except level dens. Records of recent fox activity at hill dens was not significantly higher than at other den types (Fisher's exact test $p=0.15$, one-tailed) and the occurrence of cubs at hill dens was not significantly higher than at other den types (Fisher's exact test $p=0.06$, one-tailed).

In 1992, dens with signs of recent activity were significantly larger than dens without signs of recent activity in terms of both total number of entrances and diameter (Table 1). Dens recorded as breeding dens in the study period were significantly larger than other dens in terms of the total and used number of entrances (Table 1). The mean number of used entrances at active dens was $6.3 \pm 4.8 \mathrm{SD}$ (range $1-16, \mathrm{n}=9$ ). At the two breeding dens found in 1992, used entrances made up $86 \%$ and $94 \%$ of the total number of entrances respectively, against 1-25\% (mean $13 \% \pm$ 3.7 SE, $\mathrm{n}=7$ ) in non-breeding dens in use.

Dens with signs of recent activity or dens that had been used as breeding dens were more conspicuous than dens where no activity had been recorded $\left(\chi^{2}=10.6, \mathrm{df}=2, p<0.005\right)$ and $\left(\chi^{2}\right.$ $=9.8, \mathrm{df}=2, p<0.01)$ respectively.

The mean number of entrances protected from the dominant summer winds, i.e., directed towards northwest to east (clockwise) (18.86 $\pm 15.3 \mathrm{SD}, \mathrm{n}=7)$ was significantly larger than the number of entrances facing southeast to west $(9.86 \pm 5.30 \mathrm{SD}$, $\mathrm{n}=7)(\mathrm{z}=1.96, p<0.05)$. 
TABLE 1. Comparison of the mean (SD) number of entrances between den types, dens of different conspicuousness scores and use.

\begin{tabular}{|c|c|c|c|c|c|c|c|c|c|c|c|c|c|c|c|c|}
\hline & \multicolumn{2}{|c|}{ Den type } & \multicolumn{2}{|c|}{$\begin{array}{l}\text { Signed rank } \\
\text { test }\end{array}$} & \multicolumn{3}{|c|}{$\begin{array}{l}\text { Conspicuousness } \\
\text { c-score }\end{array}$} & \multicolumn{2}{|c|}{$\begin{array}{c}\text { Kruskal-Wallis } \\
\text { test }\end{array}$} & \multicolumn{2}{|c|}{$\begin{array}{c}\text { Recent } \\
\text { activity (1992) }\end{array}$} & \multicolumn{2}{|c|}{$\begin{array}{l}\text { Signed rank } \\
\text { test }\end{array}$} & \multicolumn{2}{|c|}{$\begin{array}{c}\text { Breeding } \\
\text { den }(1990-92)\end{array}$} & $\begin{array}{l}\text { Signed rank } \\
\text { test }\end{array}$ \\
\hline & Level & Other & $\mathrm{z} ;$ & $p$ & 0 & 1 & 2 & $\mathrm{H}$; & $p$ & + & - & $\mathrm{z}$; & $p$ & + & - & $\mathrm{z} ; p$ \\
\hline \multicolumn{17}{|l|}{$\begin{array}{l}\text { Mean (SD) no. } \\
\text { of entrances }\end{array}$} \\
\hline (No. of dens) & $(\mathrm{n}=4)$ & $(\mathrm{n}=12)^{1}$ & & & $(\mathrm{n}=9)$ & $(n=6)$ & $(\mathrm{n}=2)$ & & & $(\mathrm{n}=10)$ & & $(\mathrm{n}=7)$ & & & $(\mathrm{n}=5)$ & $(\mathrm{n}=12)$ \\
\hline Used & $\begin{array}{c}3.8 \\
(2.6)\end{array}$ & $\begin{array}{l}3.5 \\
(5.4)\end{array}$ & 0.7 & $0.49 \mathrm{~ns}$ & $\begin{array}{c}0.3 \\
(0.7)\end{array}$ & $\begin{array}{l}5.3 \\
(3.9)\end{array}$ & $\begin{array}{l}11.0 \\
(7.1)\end{array}$ & \multicolumn{2}{|c|}{$10.6 ;<0.005$} & & & & & $\begin{array}{l}7.8 \\
(6.3)\end{array}$ & $\begin{array}{c}1.5 \\
(2.2)\end{array}$ & $-2.1 ;<0.05$ \\
\hline Aged & $\begin{array}{c}17.0 \\
(15.0)\end{array}$ & $\begin{array}{c}6.3 \\
(9.9)\end{array}$ & 1.9 & $0.06 \mathrm{~ns}$ & $\begin{array}{c}3.2 \\
(3.3)\end{array}$ & $\begin{array}{c}16.8 \\
(12.8)\end{array}$ & $\begin{array}{c}17.5 \\
(23.3)\end{array}$ & $3.4 ;$ & $0.18 \mathrm{~ns}$ & $\begin{array}{c}13.8 \\
(14.1)\end{array}$ & $\begin{array}{l}3.9 \\
(3.4)\end{array}$ & 0.9 ; & $0.35 \mathrm{~ns}$ & $\begin{array}{c}14.4 \\
(14.4)\end{array}$ & $\begin{array}{c}7.8 \\
(10.8)\end{array}$ & $0.4 ; \quad 0.36 \mathrm{~ns}$ \\
\hline Collapsed & $\begin{array}{c}14.3 \\
(24.6)\end{array}$ & $\begin{array}{l}1.8 \\
(3.1)\end{array}$ & 1.3 & $0.18 \mathrm{~ns}$ & $\begin{array}{l}1.2 \\
(2.4)\end{array}$ & $\begin{array}{c}10.2 \\
(20.1)\end{array}$ & $\begin{array}{l}4.5 \\
(6.4)\end{array}$ & 3.4 & $0.18 \mathrm{~ns}$ & & & & & $\begin{array}{l}2.6 \\
(3.7)\end{array}$ & $\begin{array}{c}5.7 \\
(14.5)\end{array}$ & $0.4 ; \quad 0.34 \mathrm{~ns}$ \\
\hline Total & $\begin{array}{c}35.0 \\
(24.4)\end{array}$ & $\begin{array}{l}11.6 \\
(13.4)\end{array}$ & 1.8 & $0.08 \mathrm{~ns}$ & $\begin{array}{c}4.7 \\
(3.5)\end{array}$ & $\begin{array}{c}32.3 \\
(17.7)\end{array}$ & $\begin{array}{c}33.0 \\
(22.6)\end{array}$ & \multicolumn{2}{|c|}{$12.0 ;<0.005$} & $\begin{array}{c}27.6 \\
(18.4)\end{array}$ & $\begin{array}{l}3.8 \\
(3.4)\end{array}$ & \multicolumn{2}{|c|}{$3.3 ;<0.005$} & $\begin{array}{c}24.8 \\
(14.0)\end{array}$ & $\begin{array}{c}14.9 \\
(19.8)\end{array}$ & $-1.7 ;<0.05$ \\
\hline \multirow[t]{2}{*}{$\begin{array}{l}\text { Diameter } \\
\text { (no. of dens) }\end{array}$} & $(\mathrm{n}=3)$ & $(\mathrm{n}=10)^{2}$ & & & $(\mathrm{n}=6)$ & $(n=6)$ & $(\mathrm{n}=2)$ & & & $(\mathrm{n}=9)($ & $(\mathrm{n}=4)^{2}$ & & & $(n=4)$ & $(\mathrm{n}=9)^{2}$ & \\
\hline & $\begin{array}{l}34.0 \\
(5.3)\end{array}$ & $\begin{array}{c}10.3 \\
(12.8)\end{array}$ & \multicolumn{2}{|c|}{$2.3 ;<0.05$} & $\begin{array}{l}1.8 \\
(2.1)\end{array}$ & $\begin{array}{c}25.7 \\
(12.4)\end{array}$ & $\begin{array}{c}24.0 \\
(14.1)\end{array}$ & $2.1 ;$ & $0.34 \mathrm{~ns}$ & $\begin{array}{c}22.6 \\
(13.6)\end{array}$ & $\begin{array}{c}0.5 \\
(0.6)\end{array}$ & \multicolumn{2}{|c|}{$2.9 ;<0.005$} & $\begin{array}{c}23.0 \\
(11.1)\end{array}$ & $\begin{array}{c}12.6 \\
(16.4)\end{array}$ & $-1.2 ; \quad 0.12 \mathrm{~ns}$ \\
\hline
\end{tabular}

1 the ruin den has been excluded; ${ }^{2}$ the diameter is known for 14 dens and the ruin den has been excluded.

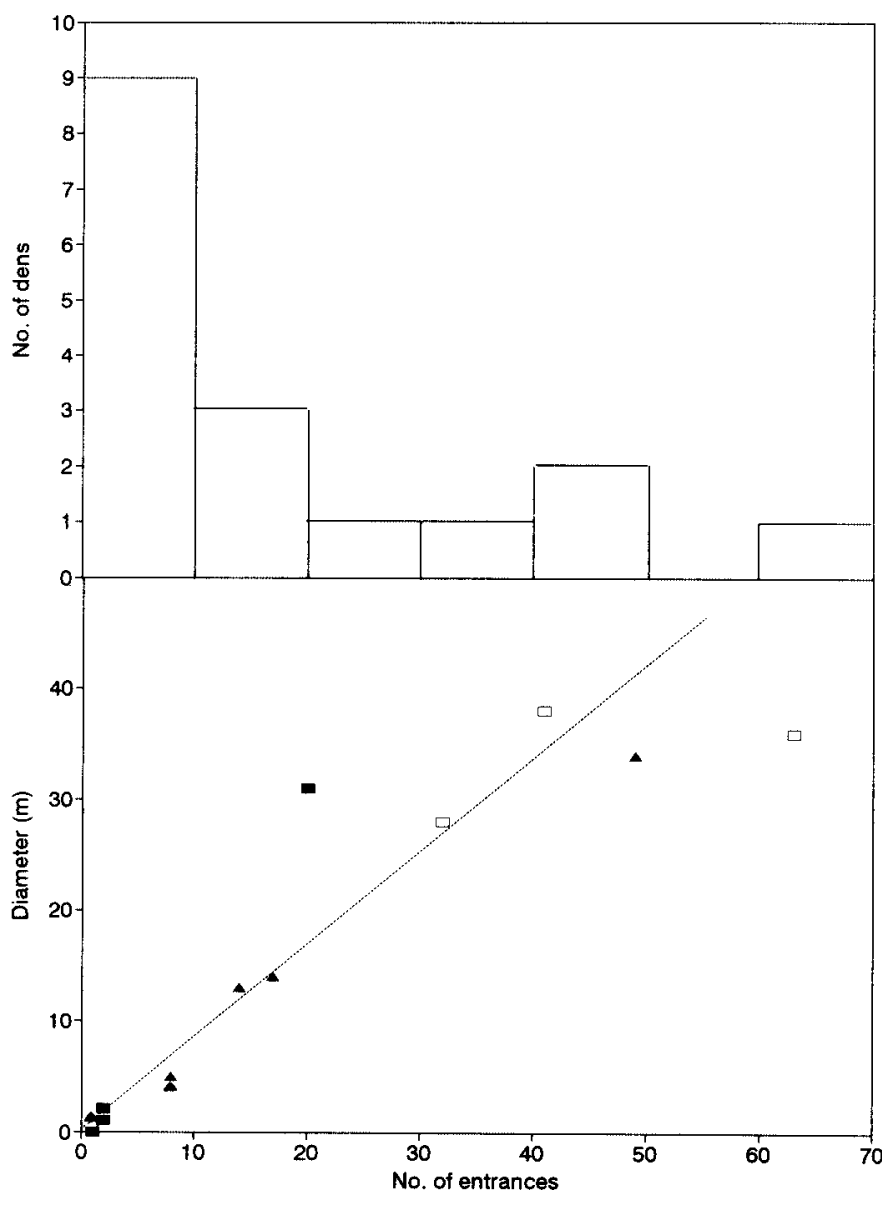

FIG. 3. The den size distribution in terms of number of entrances (histogram) and the relation between the number of entrances and the diameter of the den. The regression line for the total number of dens is shown: $\mathrm{y}=2.1+0.69 \mathrm{x}(\mathrm{t}=7.6, p$ $<0.001)$. The regression lines for hill dens $(\boldsymbol{\Delta})$ and rock dens $(\boldsymbol{\square})$ are: $\mathrm{y}=-0.80+$ $0.82 \mathrm{x}(\mathrm{t}=19.9, p<0.001)$ and $\mathrm{y}=-2.08+1.65 \mathrm{x}(\mathrm{t}=69.6, p<0.0005)$ respectively. No significant relation between number of entrances and the diameter was found for level $(\square)$ dens $(\mathrm{t}=0.71, p=0.61)$.
Soil samples of eight dens contained more than $90 \%$ sand grains (mean $94.0 \% \pm 1.2 \mathrm{SE}$ ) and less than $10 \%$ silt and clay. They were therefore classified as sand: one sample as fine sand, one as coarse sand and the rest as medium sand. Two samples, one from the ruin den and one from a scree den, contained mainly decaying plant material.

\section{Vegetation Analysis}

At the ten dens in use during the study period, 52 species of vascular plants, 19 of mosses and 65 of lichens were recorded in the Raunkier's circles. Sixteen species (12\%) occurred in the Raunkier's circles of five dens or more (Table 2). Eight species occurred significantly more frequently on the den than in the surrounding area, with Stellaria longipes, Salix glauca and Poa arctica showing the highest significance. Three lichen species (Cetraria islandica, Cladonia mitis and Stereocaulon alpinum) occurred more frequently in the surrounding area than on the dens.

The vegetation differed significantly between the den area and the surrounding area at four single den sites (Table 2). Stellaria longipes was, in all four cases, the only species occurring more frequently on the den than in the surrounding area.

For all dens combined, there was no significant difference between the two areas in the mean height of willow Salix glauca (den area: $13.8 \mathrm{~cm} \pm 12.0 \mathrm{SD}, \mathrm{n}=47$; surrounding area: $10.3 \mathrm{~cm}$ $\pm 9.1 \mathrm{SD}, \mathrm{n}=35 ; \mathrm{t}=1.6, p=0.12$ ) or grass Poa spp. (den area: $16.6 \mathrm{~cm} \pm 10.7 \mathrm{SD}, \mathrm{n}=61$; surrounding area: $12.5 \pm 7.3 \mathrm{SD}$, $\mathrm{n}=35 ; \mathrm{t}=1.8, p=0.07)$.

\section{DISCUSSION}

The geographical distribution of the recorded dens reflects, to some extent, that of human activity because of the recording methods.

This study found that dens were common not only in hills and 
ridges, as found in most previous studies of arctic fox dens (Sdobnikov 1960; Danilov, 1961; Chesemore, 1969; Macpherson, 1969; Eberhardt, 1977; Østbye et al., 1978; Garrott et al., 1983; Smits et al., 1988), but also in rocks and in level ground. Arctic fox dens in association with rocks are common in Svalbard (Prestrud, 1992) and on Wrangel Island, Alaska (Uspenskii, 1958 cited in Bannikov, 1969). As many den studies in tundra areas have been made by air surveys (Chesemore, 1969; Macpherson, 1969; Garrott et al., 1983; Smits et al., 1988), it is unknown if the small number of rock dens observed in tundra areas other than on Svalbard, Wrangel Island and Disko Island is due to difficulties with detection of rock dens from the air, a lack of rocky habitats in the tundra (Prestrud, 1992), or rock dens not being attractive to foxes living in the tundra (Macpherson, 1969).

The active soil layer on Disko Island seems deeper (about $3 \mathrm{~m}$ to the permafrost in level ground in late July and August) than in other areas where depth to permafrost has been measured. In Siberia and Yukon Territory, the depth to permafrost ranged between $40-110 \mathrm{~cm}$ at the den and 6-95 $\mathrm{cm}$ in the adjacent area (Danilov, 1961; Smits et al., 1988). This study found that level dens were larger than other den types, and the relation between the number of entrances and the diameter was less predictable. Hence, foxes may be forced to dig more horizontally in level ground than in slopes and ridges, depending on the depth to the permafrost layer.

In general, the mean size of arctic fox dens varies greatly between areas, in terms of both area covered by the den and number of entrances. The mean number of entrances noted in earlier studies ranges from 9.8 in Svalbard (Prestrud, 1992) to 33.0 in the tundra plains of Alaska (Garrott et al., 1983). Three factors have been suggested to influence reported den size: 1) differences in measurement techniques among authors (Prestrud, 1992), 2) differences in the age of the dens (Macpherson, 1969), and 3) the size of the local fox population. The dens used more intensively are larger (Eberhardt, 1977). Our study suggests that the local topography and climate, and thus the depth to permafrost, may also influence den size, at least in terms of area covered.

Dens found in slopes were all southfacing slopes. This is in good agreement with other investigations of arctic fox dens
TABLE 2. Occurrence of plant species, in the Raunkier's circles, on the den and in the surrounding area, compared by Chi-square test and Fisher's exact test.

\begin{tabular}{|c|c|c|c|c|c|c|}
\hline & \multirow[t]{2}{*}{$\begin{array}{c}\text { No. of } \\
\text { den sites }\end{array}$} & \multirow[t]{2}{*}{$\begin{array}{l}\text { Total no. } \\
\text { of Raunkier } \\
\text { circles }\end{array}$} & \multicolumn{2}{|c|}{$\begin{array}{c}\text { Occurrence of } \\
\text { species in } \\
\text { Raunkier's circles }\end{array}$} & \multicolumn{2}{|c|}{ Chi-square } \\
\hline & & & Den area & $\begin{array}{c}\text { Surrounding } \\
\text { area }\end{array}$ & $€ € \chi$ & $p$ \\
\hline \multicolumn{7}{|l|}{ Dens Combined: } \\
\hline \multicolumn{7}{|l|}{ Shrubs } \\
\hline Betula nana & 6 & 192 & 16 & 27 & 3.00 & $=0.06$ \\
\hline Empetrum hermaphroditum & $m 9$ & 288 & 73 & 72 & 0.01 & $=0.91$ \\
\hline Salix glauca & 9 & 288 & $61^{1}$ & 32 & 12.45 & $<0.001$ \\
\hline Vaccinium uliginosum & 6 & 192 & 36 & 44 & 1.05 & $=0.24$ \\
\hline \multicolumn{7}{|l|}{ Herbs } \\
\hline Cerastium alpinum & 6 & 192 & 12 & 6 & 1.53 & $=0.14$ \\
\hline Equisetum arvense & 6 & 192 & $18^{1}$ & 7 & 4.60 & $<0.05$ \\
\hline Polygonum viviparum & 6 & 192 & 5 & $17^{1}$ & 6.21 & $<0.01$ \\
\hline Pyrula grandiflora & 7 & 224 & 47 & 35 & 2.33 & $=0.10$ \\
\hline Stellaria longipes & 9 & 288 & $49^{1}$ & 13 & 25.18 & $<0.001$ \\
\hline \multicolumn{7}{|l|}{ Sedge } \\
\hline \multirow{2}{*}{\multicolumn{7}{|c|}{ Grass }} \\
\hline & & & & & & \\
\hline Poa arctica & 9 & 288 & $44^{1}$ & 20 & 10.63 & $<0.001$ \\
\hline \multicolumn{7}{|l|}{ Mosses } \\
\hline Dicranum sp. & 5 & 160 & 24 & 35 & 2.69 & $=0.07$ \\
\hline \multicolumn{7}{|l|}{ Lichens } \\
\hline Cetraria islandica & 7 & 224 & $27^{1}$ & 49 & 8.78 & $<0.005$ \\
\hline Cladonia coccifera & 5 & 160 & 13 & 19 & 0.98 & $=0.24$ \\
\hline Cladonia mitis & 7 & 224 & 13 & $25^{1}$ & 3.83 & $<0.05$ \\
\hline Stereocaulon alpinum & 6 & 192 & 13 & $33^{1}$ & 10.32 & $<0.001$ \\
\hline Single Dens: & & & & & \multicolumn{2}{|c|}{$\begin{array}{c}\text { Fisher's exact test } \\
\text { (two-tailed) } \\
p<\end{array}$} \\
\hline Den site A & 1 & 32 & & & & \\
\hline Stellaria longipes & & & $9^{1}$ & 1 & & \\
\hline Poa arctica & & & $9^{1}$ & 1 & & \\
\hline Salix glauca & & & $10^{1}$ & 2 & & \\
\hline Vaccinium uliginosum & & & 3 & $10^{1}$ & & \\
\hline Empetrum hermaphroditum & & & 2 & $8^{1}$ & & \\
\hline Den Site B & 1 & 32 & & & & \\
\hline Stellaria longipes & & & $13^{1}$ & 3 & & \\
\hline Festuca rubra & & & $14^{1}$ & 7 & & \\
\hline Den Site C & 1 & 32 & & & & \\
\hline Stellaria longipes & & & $10^{1}$ & 2 & & \\
\hline Salix glauca & & & $15^{1}$ & 6 & & \\
\hline Den Site D & 1 & 32 & & & & \\
\hline Stellaria longipes & & & $9^{1}$ & 3 & & \\
\hline
\end{tabular}

${ }^{1}=$ significantly higher occurrence.

(Danilov, 1961; Bannikov, 1969; Eberhardt, 1977; Østbye et al. 1978; Garrott et al., 1983; Prestrud, 1992). In the northern hemisphere, south-facing slopes have higher soil temperatures than slopes exposed towards other directions (Danilov, 1961), and therefore have a deeper active soil layer.

Unlike previous investigations, where the overall den entrances were oriented primarily towards the south (Østbye et al., 1978; Smits et al., 1988), the den entrances in the study area were oriented more frequently towards the north and east. Danilov (1961) suggested that winds may influence the construction of the den. This appears also to be the situation in this area, where westerly and southwesterly winds dominate in the breeding season.

The arctic foxes in this study prefer to den in sand; a preference which has also been noted in other investigations (Danilov, 1961; Macpherson, 1969; Chesemore, 1969; Eberhardt, 1977; Østbye, 1978; Smits et al., 1988). Sand is warmed more readily and therefore thaws to greater depths than other types of substrate (Danilov, 1961), and it is well drained. 
The den vegetation in this area accords well with den vegetation of other investigations in that relatively fast growing and nutrition-loving species are favoured at the den, while slow growing species have poor conditions (Eberhardt, 1977; Macpherson, 1969; Garrott et al., 1983; Prestrud, 1992). The increased amount of organic material (fox scats and prey remains), and the digging activity of the foxes alter growth conditions for plants at the den (Chesemore, 1969). Although den vegetation in general differed from the surrounding vegetation in the study area, dens were not lush green, and only two of the 17 dens could be recognized from a distance. Eroded basalt is rich in minerals and base-rich (Böcher, 1981), and the fertilizing effect of fox activity on the den flora may therefore be reduced in this area.

A difference between the den vegetation and that of the surrounding area could be detected visually at eight dens which were given a c-score of 1 or 2 . The vegetation analysis, however, revealed a significant difference in the occurrence of plant species between the two areas in only four of these dens. Hence, the vegetation analysis was less sensitive than the eye to vegetational differences. On the other hand, the vegetation analysis does suggest possible species to search for in fox den surveys. It is also a more objective technique than visual judgement by an observer, as it uses transect lines and is based on the actual frequency of occurrence of plant species. Since it is fast and easy, this method of analysis also minimizes disturbance of the foxes.

The vegetation analysis here proposed may fail to detect some species growing in clusters. Adding more Raunkier's circles along the transect lines could overcome this problem, but would increase the amount of work and disturbance at the den.

Long-stalked stitchwort, Stellaria longipes, is suggested as a guide species in the search for new dens in the Disko Bay area and other areas of basalt and cretaceous geology in Greenland. This species occurred more frequently on the den than in the surrounding area; its white flowers are conspicuous; and it is common along the west coast of Greenland northwards to $71^{\circ} \mathrm{N}$ (Feilberg et al., 1984).

Because only a small proportion of the dens could be recognized from a distance, an aerial survey cannot be recommended for monitoring fox dens in this area. Such a survey, however, may be a useful supplement in the search for breeding dens, as dens with fox activity were generally more conspicuous than dens not in use.

\section{ACKNOWLEDGEMENTS}

We are grateful to the board of the Arctic Station, Godhavn, for providing local transportation, and to the staff of the station, L. Skytte, O. Sandgreen and S. Fisker, for their kindness and supply of information on the Greenlandic sea. S. Lægaard identified the Poaceae, the Cyperaceae and the mosses, while S. Svane identified the lichens. H. Baagøe and B. Muus kindly read an early draft of the manuscript. The manuscript benefitted from criticism and suggestions from O. Frimer, P. Hersteinsson, C. Smits and two anonymous reviewers. The study was supported by grants from the Commission for Scientific Research in Greenland (J.nr. 5.111/40 0.234-91) and the Carlsberg Foundation (Ans. 91-0355/20).

\section{REFERENCES}

BANNIKOV, A.G. 1969. Arctic fox in the U.S.S.R. In: Fuller, W.A., and Kevan, P.G., eds. Productivity and conservation in northern circumpolar lands. International Union for Conservation of Nature and Natural Resources Publication, New Series 16:121-130.

BÖCHER, T.W. 1959. Floristic and ecological studies in middle West Greenland. Meddelelser om Grønland 156:1-69.

. 1963. Phytogeography of middle West Greenland. Meddelelser om Grønland 148. 290 p.

. 1981. Hovedtræk af Grønlands plantegeografi. In: Nørrevang, A., and Lund $\varnothing$, J., eds. Danmarks Natur 11. 350-365.

CHESEMORE, D.L. 1969. Den ecology of the Arctic fox in northern Alaska. Canadian Journal of Zoology 47:121-129.

DANILOV, D.N. 1961. Den sites of the arctic fox (Alopex lagopus) in the east part of Bol'shezemel'skaya tundra. Problems of the North 2:223-229.

EBERHARDT, L.E. 1977. The biology of arctic and red foxes on the North Slope. M.S. thesis, University of Alaska, Fairbanks. 125 p.

ERICSON, M., and GRUNDSTEN, C. 1980. Flygbildstolkning av fjällrävens Alopex lagopus lyor. Fauna och Flora 75:188-198.

ESCHER, A., and STUART, W. 1976. Geology of Greenland. Odense: Andelsbogtrykkeriet. $603 \mathrm{p}$.

FEILBERG, J., FREDSKILD, B., and HOLT, S. 1984. Flowers of Greenland. Ringsted, Denmark: Forlaget Regnbuen. 100 p.

GARROTT, R.A., EBERHARDT, L.E., and HANSON, W.C. 1983. Arctic fox den identification and characteristics in northern Alaska. Canadian Journal of Zoology 61:423-426.

LOLL, S., ed. 1993. Execustat 3.0. Belmont, California: Duxbury Press. $538 \mathrm{p}$.

LYNGE, B. 1937. Lichens from West Greenland collected chiefly by Th. M. Fries. Meddelser om Grønland 118(8). 225 p.

MacPHERSON, A.H. 1969: The dynamics of Canadian arctic fox populations. Canadian Wildlife Service Report Series 8. 52 p.

McGILL, R., TUKEY, J.W., and LARSEN, W.A. 1978. Variations of box plots. The American Statistician 32:12-16.

MOGENSEN, G.S. 1985. Illustrated moss flora of arctic North America and Greenland. 1. Polytrichacea. Meddelelser om Grønland. Bioscience 17. $57 \mathrm{p}$.

- 1986. Illustrated moss flora of arctic North America and Greenland. 2. Sphagnaceae. Meddelelser om Grønland. Bioscience 18. $61 \mathrm{p}$.

- 1987. Illustrated moss flora of arctic North America and Greenland. 3. Andreaeobryaceae - Tetraphidaceae. Meddelelser om Grønland. Bioscience 23.36 p.

MUELLER-DOMBOIS, D., ANDELLENBERG, H. 1974. Aims and methods of vegetation ecology. New York: J. Wiley and Sons. $547 \mathrm{p}$.

NIELSEN, S.M. 1991. Fishing arctic foxes Alopex lagopus on a rocky island in West Greenland. Polar Research 9:211-213.

ØSTBYE, E., SKAR, H.J., SVALASTOG, D., and WESTBY, K. 1978. Arctic fox (Alopex lagopus) and red fox (Vulpes vulpes) on Hardangervidda; den ecology, distribution and population status. Meddelelser fra Norsk Viltforskning 3.66 p. 
PEDERSEN, A. 1959. DerEisfuchs Alopexlagopus Linné. WittenbergLutherstadt: Ziemens Verlag.

PORSILD, M.P. 1920. The flora of Disko Island and the adjacent coast of West Greenland. Meddelelser om Grønland 58. 155 p.

PRESTRUD, P. 1992. Physical characteristics of arctic fox (Alopex lagopus) dens in Svalbard. Arctic 45:154-158.

PULLAINEN, E., and ALA-KOTILA, N. 1982. Population status of the arctic fox, Alopex lagopus, in Utsjoki, northern Finland, in 1980-1981. Aquilo Ser. Zoologica 21:53-56.

SALOMONSEN, F., ed. 1990. Grønlands fauna (Second edition). København: Gyldendal. 464 p.
SDOBNIKOV, V.M. 1960. The arctic fox in Taymyr. Problems of the North 1:229-238.

SMITS, C.M.M., SMITH, C.A.S., and SLOUGH, B.G. 1988. Physical characteristics of arctic fox (Alopex lagopus) dens in northern Yukon Territory, Canada. Arctic 41:12-16.

SOIL SURVEY STAFF. 1975. Soil taxonomy: A basic system of soil classification for making and interpreting soil surveys. Washington, D.C.: U.S. Department of Agriculture Handbook 436. 734 p.

ZETTERBERG, H. 1945. Två fredlösa. Uppsala: J.A. Lindblads Förlag. $211 \mathrm{p}$. 